\title{
ПЕДАГОГІЧНІ РЕКОМЕНДАЦЇ̈ ЩОДО ПРИСТОСУВАННЯ ДИХАЛЬНОЇ СИСТЕМИ ДО УМОВ ГРИ НА ДУХОВИХ ІНСТРУМЕНТАХ
}

Палаженко О. П. Педагогічні рекомендащії щодо пристосування дихальної системи до умов гри на духових інструментах.

У статті систематизовано та методично обтрунтовано основні педагогічні рекомендачї щодо пристосування дихальної системи до умов гри на духових інструментах.

Ключові слова: дихання, вдих, видих, виконавське дихання, вправи для дихальної системи.

Палаженко О. П. Педагогические рекомендаџии по поводу приспособления дыхательной системы к условиям игры на духовых инструментах.

В статье систематизированы и методически обоснованы основные педагогические рекомендации относительно приспособления дыхательной системы к условиям игры на духовых инструментах.

Ключевые слова: дыхание, вдох, выдох, исполнительское дыхание, упражнения для дыхательной системы.

Palazhenko O. Pedagogical recommendations for adaptation to the conditions of the respiratory system play a wind instrument.

In the article it is systematized and methodically grounded basic pedagogical recommendations in relation to adaptation of the respiratory system to the terms of game on wind instruments.

Key words: breathing, inhalation, exhalation, performance breathing, exercises for the respiratory system.

Процес гри на духових інструментах є досить багатогранним явищем, яке передбачає фізіологічні і педагогічні навички, що формуються під час навчання гри на різних видах дерев'яних чи мідних духових інструментах. Одним із найважливіших етапів для досягнення високої виконавської майстерності $є$ правильне пристосування дихальної системи, від якої залежить видобування звука на музичному інструменті. Питання навчання «методично правильного дихання» музиканта-духовика є досить суперечливим у музичній педагогіці і методиці навчання гри на духових інструментах, тому що деякі педагоги вважають, що дихання має самостійно розвиватися в процесі гри на інструменті, якщо правильно організувати роботу дихальної системи i артикуляційного апарату, інші ж стверджують, що диханню в процесі виконання навчитися не можна - його важливо навчитися відчувати. Тому вважаємо, що доцільною й актуальною $\epsilon$ проблема формування та удосконалення навичок дихання й пристосування артикуляційного апарату та всієї дихальної системи до умов гри на духових інструментах.

На нашу думку, необхідно виробити певну систему вправ для розвитку дихання. Тому мета статті полягає в обгрунтуванні й систематизації основних педагогічних рекомендацій щодо пристосування дихальної системи до умов гри на духових інструментах.

Передовсім звернемося до сучасних наукових відомостей про процес дихання. Під час гри на духових інструментах повітря вдихається через ніс $\mathrm{i}$ 
рот одночасно, причому більше через рот і менше через ніс. Вдихуване через ніс повітря, проходячи вузькими носовими раковинами, залишається на поверхні слизової оболонки носа у вигляді дрібних часток пилу, ніби фільтрується. Цьому сприяють також і дрібні волосини, розташовані поблизу входу в ніс. Якщо повітря вдихається через рот, то воно не встигає очиститися, зволожитися й зігрітися раніше, ніж потрапити в дихальні шляхи. Цю обставину необхідно врахувати всім, хто грає на духових інструментах, і частіше вдихати повітря через ніс [1, с. 76].

Диханням називається обмін газів між організмом і навколишнім середовищем. При цьому легені, дихальне горло, бронхи, порожнина рота, носоглотка $\epsilon$ тим резервуаром, у якому накопичується потрібне для звукоутворення повітря, а сила м'язів діафрагми, грудної клітини й черевного пресу - джерелом енергії, що рухає накопичений запас повітря й спонукає його за допомогою мови виходити назовні через отвір між губами, утворюючи звук.

Насамперед, кожному педагогу в процесі занять із учнем-духовиком необхідно виробити плавний i поступовий видих на опорі, що буде правильним результатом навчання виконавського дихання.

Велике значення під час гри на духових інструментах має оволодіння раціональним способом вдиху i видиху. Процес пристосування дихальної системи до цих умов відбувається повільно і поступово. Головне завдання будь-якого духовика (від флейтиста до тубіста) - навчитися правильно дихати.

Слід зазначити, що виконавське дихання містить дві фази: короткий, швидкий вдих (через рот) i тривалий видих. Особливо важливо, що тривалість видиху залежить не тільки від характеру і будови музичних фраз, але й від ігрових намірів музиканта. Усі педагоги-музиканти стверджують, що дихати потрібно в ритмі музики, тобто вдих має відбуватися в тому темпі, у якому виконується твір [3, с. 51].

У виконавській практиці музикантів, які грають на духових інструментах, застосовуються два види дихання - діафрагмальне (нижнє) i грудочеревне (змішане). Часто музикант сам не знає, яким типом дихання він користується, і його уявлення про це може не збігатися з точними спостереженнями за диханням, зафіксованими за допомогою апаратури.

Діафрагмальний вид дихання застосовується зазвичай під час гри коротких музичних фраз, або в тому випадку, коли в музиканта в розпорядженні мала кількість часу для вдиху. Коли часу для вдиху достатньо, то вдаються до глибшого вдиху - грудочеревного, що дозволяє без перенапруження виконувати досить тривалі музичні фрази.

Розвиток дихання може здійснюватися двома способами: без інструменту і в процесі гри на ньому. Перший метод має тренувальний характер, а другий пов'язаний з грою тривалих звуків, спеціальних етюдів, повільною, кантиленною музикою.

Виконавське дихання виховується поступово і систематично. Існує ряд вправ, прийомів, спрямованих на постановку і закріплення виконавського 
дихання, яке доводиться до автоматизму і стає природним як для гри на духовому інструменті, так і для звичайної мови. Ці вправи дуже прості, i тривалість їх сягає всього 20-25 хвилин на день [6, с. 32].

Така «гімнастика» позитивно впливає на роботу дихальної мускулатури і на організацію техніки правильного, раціонального вдиху і видиху.

Тому наведемо деякі педагогічні та методичні рекомендації щодо ефективного навчання правильному виконавському диханню. Але спочатку зазначимо, що виконувати деякі вправи краще біля великого дзеркала, тому потрібен постійний самоконтроль:

а) стежте, щоб корпус був вільним, плечі розгорненими;

б) дихати легко і вільно, не перебираючи повітря;

в) стежити, щоб плечі і груди при вдиху не піднімалися;

г) вдих маленький, безшумний;

д) видих довгий, еластичний;

е) у процесі видиху слід утримувати «опору», тобто м'язи пресу в процесі видиху не повинні провалюватися.

Під час виконання вправ можливе легке запаморочення. Відпочивши близько хвилини можна продовжувати.

Основними рекомендаціями під час виконання таких вправ будуть: виконувати спокійно, не перебільшувати видих, дотримуючись стану спокою в усьому тілі. Намагайтеся не перебирати повітря при вдиху. Головне, щоб вдих і видих проходив без перебільшення, був вільним і природним.

Найбільш ефективною для розвитку «повного дихання» може стати така вправа. Лежачи на спині, покладіть долоню однієї руки на груди, а долоню іншої - на нижню частину живота. Потім зробіть глибокий вдих таким чином, щоб бічні і передні стінки живота випнулися вперед i в сторони, піднімаючи вашу долоню. Але грудна клітка, яка контролюється іншою вашою рукою, має залишатися в спокої. Навчавшись виконувати цю вправу лежачи, можна перейти до виконання його стоячи.

У положенні стоячи покладіть руку на живіт для контролю дихання i зробіть повільний вдих, рахуючи про себе до чотирьох (краще використовувати простий метроном). Не затримуючи дихання, повільно видихайте, знову рахуючи до чотирьох. Відчуйте, як живіт надувається при вдиху і здувається при видиху. Якщо ви погано відчуваєте рух живота, спробуйте виконати цю вправу: сидячи, нахиливши корпус максимально вперед, голову наблизити до колін, а руками обійняти себе під колінами (в замок). На повільному вдиху має 3'явитися відчуття розширення ділянки живота і спини. Ви неодмінно відчуєте, що нікуди не поспішаюючи дихати це правильне відчуття.

Наступна вправа сприяє підвищенню сили й еластичності міжреберних м'язів. Вимоги вправи: початкове положення - стоячи. Корпус прямий, плечі розгорнені, руки розслаблені. Притуливши до губ мундштук (без інструмента), потрібно взяти повне дихання. Потім, посилаючи повітря у мундштук, намагайтеся утримувати груди в сталому (початковому) 
положенні. Задля ускладнення тренування можна посилати повітряний струмінь у мундштук енергійними поштовхами з вимовою складу «то» або «до». Після кожного складу необхідно робити невелику паузу, при цьому потрібно намагатися утримувати грудну клітку в сталому положенні. Цю вправу слід повторити без перерви 5-8 разів.

Корисною для тренування діафрагми і м'язів черевного пресу є така вправа:початкове положення - стоячи, ноги на ширині плечей. Присідаючи, потрібно зробити глибокий і повний вдих. Затримавши дихання на видиху, слід встати і злегка нахилитися вперед, упираючись руками в верхню частину стегон. У такому положенні потрібно енергійно втягнути, а потім розслабити передню стінку живота.

Ускладнений тип тренування повного дихання, який допомагає знайти зону дихальної опори, полягає в тому, що цю вправу слід робити в положенні лежачи на спині. Для їі виконання вам знадобиться який-небудь вантаж вагою 1,5-2 кг і розміром 40х20 см (наприклад, кілька книг). Цей вантаж укладається на нижню частину живота. Роблячи глибокий вдих носом i розводячи при цьому руки в сторони долонями вгору, потрібно рухом передньої стінки живота підняти вантаж якомога вище. Далі на повільному видиху слід якомога довше затримати вантаж м'язами в піднятому положенні і робити повільний видих через рот. Видихати повітря потрібно плавно, намагаючись якомога довше не опускати груди, наче вдих триває під час видиху.

Можна запропонувати такий варіант вправи на повне дихання, яка виконується в положенні стоячи. У результаті повного вдиху розширюються нижні ребра, а м'язи нижньої частини черевного преса напружуються. Видихати повітря слід рівним концентрованим струменем через вузьку щілину губ. Уявіть, що ви дуєте на палаючу свічку, намагаючись погасити вогонь. Роботу міжреберних м'язів корисно контролювати долонями рук. Заняття вокалом і гра на духових інструментах мають спільні грані, а саме: і вокалісти, i музиканти-духовики використовують своє дихання в процесі звукоутворення. Наступні кілька вправ запозичено у вокалістів і трохи адаптовано для занять у процесі навчання гри на духових інструментах.

Досить цікавою є вправа «Собачка». Придивіться, як здіймаються боки в собаки, яка дихає, висолопивши язика, і ви зрозумієте, чому ця вправа має назву «собачка». Вдихніть і видихніть на складі «хо-о-о ...». Запам'ятайте положення губ, горла і щелепи. Тепер чергуйте швидкі вдихи-видихи в цьому положенні. Цю вправа корисно виконувати перед дзеркалом. Сядьте на стілець, спершись на його спинку, розслабте плечі і шию. Виконуючи вправу, стежте, щоб плечі не піднімалися.

Наступна вправа для розвитку «відкритого» звука. Намацайте на гортані кадик і прослідкуйте за його рухами під час позіхання. Кадик починає опускатися вниз. Треба навчитися фіксувати цей стан під час гри на духових інструментах. Опущена, а значить вільна і трохи розширена гортань сприяє гарному природному виходу повітря, що, свою чергу, безумовно, позитивно позначиться на тембрі інструмента. Але не треба насильно 
тягнути гортань униз. Правильне їі відкриття досягається тільки відчуттям позіхання. Для того щоб ви ще легше змогли домогтися цього відчуття, уявіть собі, що у вас замерзли руки, і ви намагаєтеся зігріти їх своїм диханням. Видихаючи на складі «хо-о-о-о ...», у вас виходить тепле дихання. Тому можна сказати: щоб домогтися «теплого» звука на інструменті, потрібно дихати теплим повітрям.

Слід зазначити, що заняття спортом, особливо плаванням, бігом, катанням на лижах позитивно впливає на розвиток дихальної мускулатури. Під час плавання, як відомо, виробляється швидкий і глибокий вдих і відносно тривалий видих у воду, що багато в чому схоже на здійснення вдиху і видиху під час гри на духових інструментах. Найприродніше наше дихання функціонує під час сміху. Тому більше смійтеся, але і про роботу м'язів не забувайте.

Отже, ми навели основні педагогічні рекомендації щодо пристосування дихальної системи до умов гри на духових інструментах, а також найважливіші вправи для розвитку дихання музиканта-духовика.

\section{Література}

1. Апатский В. Н. Основы теории и методики духового музыкальноисполнительскогоискусства: [учеб. пособие] / В. Н. Апатский. - К. : НМАУ им. П. И. Чайковского, 2006. - 432 с.

2. Вовк Р. А. Історія, акустична природа і виразні можливості аплікатури кларнета: дис.... канд. мистецтвознавства: 17.00.03 / Р. А. Вовк. - К., 2004. - 204 с.

3. Діков Б. Методика навчання гри на духових інструментах / Б. Діков. - М., 1962. - 116 с.

4. Орвид Г. Некоторые объективные закономерности звукообразования и искусства игры на трубе / Г.Орвид. - М. : МГК. - 30 с.

5. Рудницька О. П. Педагогіка: загальна та мистецька / О. П. Рудницька. - К., 2002. - 270 с.

6. Федоров А. Методика навчання гри на духових інструментах / А. Федоров. - М., 1975. $-158 \mathrm{c}$.

Стаття надійшла до редакції 12.04.2012 р.

\section{СТРУКТУРА ТА ЗМІСТ ІНТЕЛЕКТУАЛЬНО-ТВОРЧОГО ПОТЕНЦАЛУ ВЧИТЕЛЯ ТЕХНОЛОГІЙ}

Єфіменко С. М. Структура та зміст інтелектуально-творчого потенціалу вчителя технологій.

У статті запропоновано узагальнену структуру інтелектуально-творчого потенціалу вчителя технологій. Розкрито структурні складники изього особистісного утворення.

Ключові слова: інтелектуальний потенціал, творчий потенціал, інтелектуально-творчий потенціал вчителя технологій.

Ефименко С. Н. Структура и содержание интеллектуально-творческого потенциала учителя технологий.

В статье предложена обобщенная структура интеллектуально-творческого потенциала учителя технологий. Раскрыты структурные составляющие данного личностного образования.

Ключевые слова: интеллектуальный потенцичал, творческий потенциал, интеллектуально-творческий потенцииал учителя технологий.

Efimenko S. The structure and content, creativity intelektualno teacher technology.

The article offers the generalized structure of intellectually-creative potential of teacher of technologies. An author characterizes the structural components of this personality formation.

Key words: intellectual potential, creative potential, intellectually-creative potential of teacher of technologies. 